\title{
Nutrient Utilizations and Intestinal Morphology of Broilers Treated with Lactobacillus plantarum AKK30 - Oligosaccharides Synbiotic
}

\author{
H. Julendraa, ${ }^{\mathrm{a}, \mathrm{b}}$, A. Sofyan ${ }^{\mathrm{b}}$, M. F. Karimy ${ }^{\mathrm{b}}$, Abinawanto ${ }^{\mathrm{a}, *}$, , , Yasman $^{\mathrm{a}}$ \\ aDepartment of Biology, Faculty of Mathematics and Natural Sciences, Universitas Indonesia, \\ Jalan Lingkar Kampus Raya, Depok, Jawa Barat 16424, Indonesia \\ 'Research Group of Bio-Feed Additive Technology, Research Division for Natural Product Technology (BPTBA), \\ Indonesian Institute of Sciences (LIPI), \\ Jalan Jogja-Wonosari Km. 31.5 Gading, Playen, Gunungkidul, D.I. Yogyakarta 55861, Indonesia \\ *Corresponding author: abinawanto.ms@sci.ui.ac.id \\ (Received 08-01-2020; Revised 31-03-2020; Accepted 07-04-2020)
}

\begin{abstract}
Lactobacillus plantarum AKK30 inoculum in de Maan Rogosa Sharpe Broth (MRSB) grown on media containing oligosaccharides (inulin or mannan oligosaccharides/MOS) was studied in vitro and in vivo. In vitro assay was conducted to characterize metabolite profiles and its effect on pathogenic bacteria, while in vivo assay was conducted to study the metabolic energy, nitrogen retention, and intestinal morphology of broilers. A total of 24 male broilers-40-day-old (average body weight= $1.725 \pm 0.05 \mathrm{~kg}$ ) strains Cobb-500 were used, where 20 birds were added $1 \%$ inoculum $L$ plantarum AKK30 of daily intake and randomly distributed in five treatments and four replications consisted of: A) MRSB + L. plantarum AKK-30 (107 $\left.\mathrm{cfu} \mathrm{g}^{-1}\right)$; B) MRSB + inulin 0.5\% $\left(\mathrm{w} \mathrm{v} \mathrm{v}^{-1}\right)$; C) MRSB + MOS 0.5\%(w $\left.\mathrm{v}^{-1}\right)$; D) L. plantarum AKK-30 (10 $\left.\mathrm{cfu}^{-1}\right)+$ MRSB + inulin $0.5 \%\left(\mathbf{w ~ v}^{-1}\right)$; and E) L. plantarum AKK-30 (107 cfu $\left.\mathrm{g}^{-1}\right)+$ MRSB + MOS $0.5 \%\left(\mathrm{w} \mathrm{v}^{-1}\right)$, while 4 birds were fasted as endogenous chicken. The results showed that the highest isoleucine and threonine were found in group E. The highest oleic acid and the lowest conjugated linoleic acid (CLA) were observed in all treatments and inoculum did not affect antibacterial activity. The metabolizable energy values and nitrogen retention in group $D$ and $E$ were higher than other treatments $(\mathrm{p}<0.05)$. The lowest height of villi was observed in group A $(\mathrm{p}<0.05)$. In conclusion, the addition of oligosaccharides inulin or mannan oligosaccharide (MOS) affects the metabolite profiles of Lactobacillus plantarum AKK30 and their synbiotic effects improve intestinal morphology, metabolizable energy, and nitrogen retention in broilers.
\end{abstract}

Keywords: Lactobacillus plantarum AKK30; metabolizable energy; nitrogen retention; oligosaccharides; synbiotic

\section{INTRODUCTION}

The gastrointestinal tract (GIT) is important in poultry for digestion and poultry-host defense; however, GIT is easily attacked by the pathogenic bacteria (Sethiya, 2016). Millions of bacteria are exposed in the chicken intestine, which affects the health of the chicken (Forkus et al., 2017) and nutrients digestibility (Pourabedin \& Zhao, 2015). More than 900 species of bacteria are found in chicken intestine (Apajalahti \& Vienola, 2016). Currently, probiotics are being used as antibacterial agents, especially to suppress the population of pathogenic bacteria in the intestine (Palaniyandi et al., 2017) and nutrients digestion in chicken (Chang et al., 2019).

The use of probiotics like Lactobacillus bacteria in poultry diets has substantially increased in the last years. Furthermore, a meta-analysis of studies of probiotics across Brazil until 2005 showed that probiotics are feasible as feed additives for broilers (Filho et al., 2006).
Lactobacillus bacteria have antibacterial activity (Cao et al., 2019), improve intestinal health (Yan et al., 2017), affect intestinal morphology, and the thickness of broiler intestine (Tsirtsikos et al., 2012). Roberfroid et al. (2010) reveal that Lactobacillus genera secrete enzyme for fermenting the undigested carbohydrates that are further converted into monosaccharides.

Concentrations of fatty acids, lactic acid, and $\mathrm{pH}$ in ileum and caeca are not affected by Lactobacillus johnsonii (Olnood et al., 2015). However, there are still many problems related to the ability of Lactobacillus bacteria to increase nutrient digestibility (Wealleans et al., 2017), the growth of villi (Rodjan et al., 2018), and improve intestinal morphology (Peng et al., 2016).

Exploration of symbiosis between probiotics and oligosaccharides is needed and the expected results are the increase in protein digestibility and improve intestinal microflora in broiler. Roberfroid et al. (2010) reported that oligosaccharides were non-digestible compounds and providing beneficial effects on host physiology. 
Although those studies provided valuable information about probiotics and oligosaccharides, the potencies of synbiotic L. plantarum AKK30 and inulin to improve nutrient digestibility in chickens has not been reported. Therefore, this experiment aimed to study the nutrient utilizations and intestinal morphology of broilers treated with Lactobacillus plantarum AKK30 - oligosaccharides synbiotic on metabolizable energy, nitrogen retention, fatty acids, amino acids, inhibitory activities of pathogenic bacteria, and villi performance in broiler chicken.

\section{MATERIALS AND METHODS}

The ethical clearance for this experiment was endorsed by the commission for Clinical Experiment the Integrated Laboratory of Research and Testing (LPPT) at Universitas Gadjah Mada (UGM), YogyakartaIndonesia. The commission issued the ethical clearance certificate no. 00097/04/LPPT/VIII/2018.

\section{Experimental Design, Birds, and Diets}

The study was conducted in the laboratory of BioFeed Additive Technology and poultry closed house at the Research Division for Natural Product Technology (BPTBA), Indonesian Institute of Sciences (LIPI), Gading, Gunungkidul, Yogyakarta.

This study was conducted in two stages of experiments. The first stage was carried out by in vitro assessment of L. plantarum AKK30, which was cultured on the deMann Rogosa Sharpe/MRS broth (Oxoid) medium in combination with oligosaccharides (Inulin from Orafti, Beneo, USA and MOS from Technomos, Biochem, Germany). A completely randomized design (CRD) with five treatments consisting of A) MRSB + L. plantarum AKK-30 (10 $\left.\mathrm{cfu} \mathrm{g}^{-1}\right)$; B) MRSB + inulin 0.5\% ( $\left.\mathrm{w} \mathrm{v}^{-1}\right)$; C) $\mathrm{MRSB}+\operatorname{MOS} 0.5 \%\left(\mathrm{w} \mathrm{v}^{-1}\right)$; D) L. plantarum AKK-30 $\left(10^{7} \mathrm{cfu} \mathrm{g}^{-1}\right)+\mathrm{MRSB}+$ inulin $0.5 \%\left(\mathrm{w} \mathrm{v}^{-1}\right)$; and E) L. plantarum AKK-30 (10 $\left.\mathrm{cfu} \mathrm{g}^{-1}\right)+\mathrm{MRSB}+\operatorname{MOS} 0.5 \%\left(\mathrm{w} \mathrm{v}^{-1}\right)$, and 3 replications in each treatment. The measured parameters were optical density, anti-pathogenic bacterial activity, and the profiles of fatty acid and amino acids. $1 \%$ L. plantarum AKK30 in $2 \mathrm{~mL}$ of MRSB was added to the microtube and was vortexed, then incubated 24 hours at $37^{\circ} \mathrm{C}$. A sequence of falcon tubes filled with $10 \mathrm{~mL}$ of sterile MRSB containing inulin or MOS $(0 \%$, $\left.0.5 \% \mathrm{~W} \mathrm{v}^{-1}\right)$, then inoculated with $1 \%\left(\mathrm{v} \mathrm{v}^{-1}\right)$ starter $L$. plantarum AKK30 as previously reported by Sofyan et al. (2019).

The second experiment was carried out by in vivo assessment of synbiotic on nutrient utilization in broilers. The guideline for the treatment in this study was conducted according to McGlone (2010). The broilers diet was formulated according to the recommendations of the nutrient requirement for chicken (NRC, 1994). The ingredient content and composition of the broiler diet are shown in Table 1. Chickens were fed diets in crumble form during the experiment period. Drinking water was available ad libitum.

A total of 24 male broilers-40-day-old (average body weight $=1.725 \pm 0.05 \mathrm{~kg}$ ) strains Cobb-500 were used, where 20 birds were added $1 \%$ inoculum L plantarum AKK30 of daily intake and randomly distributed in five treatments and four replications consisted of: A) MRSB + L. plantarum AKK-30 (107 cfu g-1 $)$; B) MRSB + inulin $\left.\left.0.5 \%\left(\mathrm{w} \mathrm{v}^{-1}\right) ; \mathrm{C}\right) \mathrm{MRSB}+\operatorname{MOS} 0.5 \%\left(\mathrm{w} \mathrm{v}^{-1}\right) ; \mathrm{D}\right) L$. plantarum AKK-30 (107 $\left.\mathrm{cfu} \mathrm{g}^{-1}\right)+$ MRSB + inulin 0.5\% $\left(\mathrm{w} \mathrm{V}^{-1}\right)$; and E) L. plantarum AKK-30 (107 cfu $\left.\mathrm{g}^{-1}\right)+$ MRSB + MOS $0.5 \%\left(\mathrm{w} \mathrm{V}^{-1}\right)$, while 4 birds were fasted as endogenous chicken. The treatments were arranged in a completely randomized design. All birds were individually reared in the metabolic cage (width $30 \mathrm{~cm} \times$ length $40 \mathrm{~cm} \times$ height $40 \mathrm{~cm}$ ), and the room temperature was set at $23^{\circ} \mathrm{C}$ in a closed house system and illumination was provided for $24 \mathrm{~h}$ during the experiment. The observed parameters were apparent metabolize energy (AME) without nitrogen correction and AME with nitrogen correction (AMEn), true metabolize energy (TME) without nitrogen correction and TME with nitrogen correction (TMEn), nitrogen retention (NR), and intestinal morphology.

\section{Chemical Analysis}

Fatty acids consisted of myristic acid, palmitic acid, oleic acid, and conjugated linoleic acid (CLA) were determined by the gas chromatography-mass spectrometry (GCMS) type QP2010S (Shimadzu, Japan) equipped with column: Rtx 5 MS length: 30 meter ID: $0.25 \mathrm{~mm}$ Film: $0.25 \mu \mathrm{m}$ vehicle gas: Helium for ionization: EI 70 Ev. The n-hexane solution was used for the preparation of sample solutions, sterilizing, and heating for 2 hours. $\mathrm{N}$-hexane was evaporated; the remainder of evaporation was a sample solution. Furthermore, the sample solution was esterified by adding $\mathrm{KOH}$ methanolate (1: 2 ) and sonicated 1.5 hours at $60-70^{\circ} \mathrm{C}$. The sonication solution was extracted as well with hexane, which was evaporated using a hairdryer, and as much as $\pm 0.5 \mathrm{~mL}$ of extractant were analyzed by GCMS.

The determination of metabolites amino acid was conducted by using the ultra-performance liquid chromatography (UPLC) with column AccQ.Tag Ultra C18 $1.7 \mu \mathrm{m}$ (Waters Corp., Milford, MA, USA) and HPLC with column Lichospher $25 \mathrm{~cm}$ x $4.0 \mathrm{~mm}, 5 \mu \mathrm{m}$ from Merck. The value of the essential amino acid index (EAAI) of metabolites was estimated according to Istiqomah et al. (2009), by comparing the essential amino acid content from the standard (whole egg) as recommended by USDA (2017).

Turbidimetric measurements with a microplate reader (MultiSkan GO, Thermoscientific) at a wavelength of $590 \mathrm{~nm}$ were carried out for analyzing the growth activity of Lactobacillus plantarum AKK30. The absorbance value of the inoculum was recorded every 2 hours for 24 hours. Previously, a wheel tube containing $150 \mu \mathrm{L}$ inoculum $(1 \% 0.1 \mathrm{~mL} / 10 \mathrm{~mL})$ was inserted in a plate reader. The $\mathrm{pH}$ of the sample was measured by $\mathrm{pH}$ meter and before being used, the $\mathrm{pH}$ meter was calibrated with phosphate buffer $(\mathrm{pH}$ 6.86) and acetate buffer ( $\mathrm{pH} 4.00)$.

Antibacterial-activity assay of L. plantarum AKK 30 used twenty-five microlites of cell-free supernatant from inoculum $(1 \% 0.1 \mathrm{~mL} / 10 \mathrm{~mL})$ which was inserted into a 
Table 1. Ingredient composition (\%) and nutrients content of broiler diet

\begin{tabular}{lclr}
\hline Ingredients & Composition (\%) & Nutrients contents \\
\hline Corn & 55.00 & Metabolize energy $\left(\mathrm{kcal} \mathrm{kg}^{-1}\right)$ & $2,775.20$ \\
Rice bran & 6.00 & Crude protein (\%) & 19.14 \\
Soybean meal & 29.50 & Ether extract (\%) & 6.90 \\
Meat bone meal & 3.00 & Crude fiber (\%) & 6.91 \\
Crude palm oil & 2.50 & Ash (\%) & 6.73 \\
Premix* & 0.50 & Calcium (\%) & 1.76 \\
DCP & 0.80 & Total Phosphorus (\%) & 1.17 \\
Salt & 0.10 & Available Phosphorus (\%) & 0.49 \\
Limestone & 1.70 & Dry matter (\%) & 89.18 \\
L-Lysine & 0.60 & Amino acids (\%) & \\
DL-Methionine & 0.30 & Lysine & 0.96 \\
Total & & Methionine & 0.25 \\
\hline
\end{tabular}

Note: *Premix/kg containing vitamins A: $12.500 .000 \mathrm{IU}, \mathrm{D} 3: 2.500 .000 \mathrm{IU}, \mathrm{E}: 10.000 \mathrm{mg}, \mathrm{K} 3: 2.000 \mathrm{mg}, \mathrm{B2}: 4.000 \mathrm{mg}, \mathrm{B} 6: 1.000 \mathrm{mg}, \mathrm{Niacin}: 40.000 \mathrm{mg}$ Ca-d-Panthotenate: 4.000 mg, Choline: 20.000 mg, Fe: 30.000 mg, Cu: 5.000 mg, Mn: 80.000 mg, Co: 2.000 mg, I: 200 mg, and Zn: 70.000 mg.

**It was calculated according the cumulative content in feed formula.

blank paper disk $\varnothing 0.6 \mathrm{~mm}$ (Oxoid) and applied to agar plate containing pathogenic bacteria as an indicator of microbe, following the agar diffusion method by Bonev et al. (2008). The supernatant was obtained by centrifugation of inoculum at $4136 \times \mathrm{g}$ for 15 minutes at $4^{\circ} \mathrm{C}$. The parameters measured were diameter $(\mathrm{mm})$ of the visible clear zone of pathogenic bacteria namely Escherichia coli FNCC 0194, Staphylococcus aureus FNCC 6049, Pseudomonas aeruginosa FNCC 0063, and Salmonella pullorum ATCC 13036 in nutrient agar/NA media (Merck).

\section{Measurement of Nutrients Utilization}

The value of nutritional utilization (ME and NR) was estimated, according to Santos et al. (2015). The experiment began with 40-day-old chickens for three days. On the first day, all birds were fasted for 24 hours so that the gut was empty (Sibbald \& Wolynets, 1985). On the second day, all birds were given probiotic $(1.45 \mathrm{~mL})$ before they were fed and provided drinking water. On the third day, all excreta samples were collected, dried, milled, and weighed. Subsequently, the samples were analyzed for dry matter and chemicals. Additionally, four birds were fasted for 48 hours to estimate endogenous energy and nitrogen (N) losses. Parr ${ }^{\circledR} 6200$ Oxygen Bomb Calorimeter (Parr Instrument Company, USA) was used as an instrument to measure GE samples and the Kjeldahl method (AOAC, 2005) for analyzing nitrogen samples. ME and NR were estimated according to Sibbald \& Wolynets (1985), following the formula:

$\mathrm{AME}=[(\mathrm{Ei}-\mathrm{Ex}) / \mathrm{Fi}] \times 1000$

$\mathrm{AMEn}=\{(\mathrm{Ei}-[\mathrm{Ex}+(8.22 \times \mathrm{NR})]) / \mathrm{Fi}\} \times 1000$

$\mathrm{TME}=([\mathrm{Ei}-(\mathrm{Ex}+\mathrm{E}$ end $)] / \mathrm{Fi}) \times 1000$

$\mathrm{TMEn}=\{(\mathrm{Ei}-[\mathrm{Ex}-\mathrm{E}$ end $+(8.22 \times \mathrm{NR})]) / \mathrm{Fi}\} \times 1000$

$\mathrm{NR}=\{[\mathrm{Ni}-(\mathrm{Nex}-\mathrm{N}$ end $)] / \mathrm{Ni}\} \times 100 \%$

where AME was apparent ME $\left(\mathrm{kcal} \mathrm{kg}^{-1}\right)$, AMEn was apparent ME with nitrogen correction $\left(\mathrm{kcal} \mathrm{kg}^{-1}\right)$, TME was true ME $\left(\mathrm{kcal} \mathrm{kg}^{-1}\right)$, TMEn was true ME with nitrogen correction $\left(\mathrm{kcal} \mathrm{kg}^{-1}\right)$, Fi was feed intake (g), Ei was energy intake (g), Eexc was energy excreta (g), Eend was energy endogenous (g), Ni was nitrogen intake (g), Nexc was nitrogen excreta $(\mathrm{g})$, Nend is nitrogen endogenous (g), NR was nitrogen retention (\%), and 8.22 was coefficient of energy value from uric acid $\left(\mathrm{kcal} \mathrm{g}^{-1} \mathrm{RN}\right)$.

\section{Intestinal Morphology Analysis}

Scanning electron microscopy (Hitachi- SU3500) was used to analyze the ultrastructure of the intestine. Fifteen broiler chickens were randomly sampled and necropsied. Intestine (jejunum) was taken and sliced 4 $\mathrm{cm}$. The jejunum samples were prepared using the biological sample preparation method for scanning electron microscope (Titze \& Christel, 2016).

The preparation process of the intestinal sample includes a cleaning process involving soaking in a phosphate buffer $\mathrm{pH} 7$ for 5 hours, followed by an agitation process in an ultrasonic cleaner for $7 \mathrm{~min}$. The sample was prefixed into $2.5 \%$ glutaraldehyde solution for 24 hours and continued the fixation process in $2 \%$ tannic acids solution for 5 hours, then washed with phosphate buffer $\mathrm{pH} 7$ for 15 min 4 times. The next process was the dehydration of the sample by soaking it in alcohol with graded concentrations (50, 70, 85, 95, and absolute). After passing through the dehydration process, the sample was dried by soaking in tetra-butanol, placed in the freezer until frozen, and then put into a freeze-drier for 24 hours. The prepared sample was subsequently placed on a stub specimen and coated with Au using an ion coater tool. Further, the length of jejunum villi was evaluated by using an image processing from a scanning electron microscope (Hitachi SU-3500).

\section{Statistical Analysis}

The collected data from ME and NR were statistically analyzed by using analysis of variance (ANOVA). The Duncan's post hoc test was applied to determine the effects of treatments on the parameters measured by 
using the CoSTAT statistical software (Cohort, 2008). To evaluate the relationship between parameters from all the treatments, the data were analyzed using the principal component analysis (PCA) (Rotaru et al., 2012).

\section{RESULTS}

\section{In vitro Assay: Chemical Composition of Synbiotic Metabolites}

The results showed that all treatments contained essential fatty acids (Table 2, Figure 1) wherein the content of myristic acid and palmitate acid in treatment D (inoculum in MRSB + inulin 0.5\%) and treatment E (inoculum in MRSB + MOS 0.5\%) were higher than the other treatments, but oleic acid was higher in treatment A (inoculum in MRSB without oligosaccharides). Treatments A, D, and E contained a small amount of CLA while treatments B (MRSB + 0.5\% inulin) and C (MRSB + MOS $0.5 \%)$ did not contain CLA. Essential amino acids such as threonine and iso leucine were found with the higher concentrations in the treatment $\mathrm{E}$ compared to the other treatments. It was detected that treatment A contained the highest lysine and valine (Table 2). The essential amino acids index (EAAI) value (Table 2) showed that treatments $\mathrm{A}, \mathrm{D}$, and $\mathrm{E}$ had similar EAAI values i.e., $32.99 \%$, 32.48\%, and $32.37 \%$, respectively. However, the EAAI values in treatments A, D, and E were better than treatments B and C with EAAI values of $21.2 \%$ and $20.99 \%$, respectively. The EAAI values of treatments A, $\mathrm{D}$, and $\mathrm{E}$ were similar $(\mathrm{p}>0.05)$ that were significantly higher $(p<0.05)$ compared to those of treatments $B$ and C. These results indicated that the amino acid in probiotic could not be replaced by prebiotics.

The values of optical density of $L$. plantarum in treatments D and E were 0.9979 and 1.0062, respectively that were higher compared to that in treatment A having a low optical density of 0.0014 at the $18^{\text {th }}$ hour. At the $24^{\text {th }}$ hour, the values were similar, and it was detected that the value of optical density of L. plantarum in treatments D and E were 1.0090 and 1.0034, respectively, that were not significantly different but both of them were significantly higher than that in treatment A, i.e., 0.0079 . These results showed that the addition of inulin and MOS had a better effect on the growth of L. plantarum compared to controls.

Table 2 showed that there were inhibitory zones on treatments A, D, and E groups, but antibacterial activity was not detected on treatments B and C. These results indicated that $L$. plantarum still had antibacterial activity even though oligosaccharides were added. Bacteriocins of L. plantarum AKK30 inhibited the growth of Staphylococcus aureus, Salmonella pullorum, Escherichia coli, and Pseudomonas aeruginosa. In contrast, the antibacterial activity of L plantarum AKK30 was not affected by inulin and MOS (Figure 2).

\section{In vivo Assay: Nutrients Utilization and Intestinal Morphology}

According to Table 3, the weight of nitrogen excreta and gross energy excreta in broilers treated with inoculum in MRSB + inulin 0.5\% (Group D) were lower than those in broilers treated with the other treatments. The results of ME and NR showed that the experimental broilers treated with inoculum in MRSB + inulin 0.5\% (Group D), inoculum in MRSB + MOS 0.5\% (Group E), and MRSB + inulin 0.5\% (Group B) had similar AME, TME, and TMEn that were higher $(p<0.05)$ compared to those in Groups C and A.

The NR values in broilers treated with inoculum in group D, E, and B were similar i.e., $70.83 \%, 67.08 \%$, and $66.41 \%$, respectively. These NR values were higher $(p<0.05)$ compared to those in broilers treated with MRSB + MOS $0.5 \%$ (Group C) and inoculum in MRSB without oligosaccharides (Group A) having NR values of $56.35 \%$ and $61.85 \%$, respectively. The results showed that broilers treated with inoculum in group D appeared to be superior compared to the other treatments.

The effects of various treatments on the heights of jejunum villus are shown in Table 3 and explained in Figure 3. Broilers treated with inoculum in group D, E,

Table 2. Probiotic growth and metabolites profile of broilers treated by Lactobacillus plantarum AKK30 - Oligosaccharides

\begin{tabular}{|c|c|c|c|c|c|}
\hline \multirow{2}{*}{ Variables } & \multicolumn{5}{|c|}{ Treatments } \\
\hline & A & $\mathrm{B}$ & $\mathrm{C}$ & $\mathrm{D}$ & $\mathrm{E}$ \\
\hline Optical density at $18 \mathrm{~h}$ & $1.0009 \pm 0.2^{b}$ & $0.3193 \pm 0.1^{\mathrm{a}}$ & $0.3303 \pm 0.2^{a}$ & $0.9979 \pm 0.25^{b}$ & $1.0026 \pm 0.85^{b}$ \\
\hline Optical density at $24 \mathrm{~h}$ & $1.0024 \pm 0.1^{\mathrm{a}}$ & $0.3247 \pm 0.1^{\mathrm{a}}$ & $0.3314 \pm 0.1^{\mathrm{a}}$ & $1.0090 \pm 0.1^{\mathrm{b}}$ & $1.0034 \pm 0.25^{b}$ \\
\hline $\mathrm{pH}$ & $3.13 \pm 0.15^{\mathrm{b}}$ & $5.9 \pm 3.0^{\mathrm{a}}$ & $6.2 \pm 2.5^{\mathrm{a}}$ & $3.07 \pm 2.4^{b}$ & $3.11 \pm 4.8^{\mathrm{b}}$ \\
\hline Myristic (C14) (\%) & 2.00 & 1.81 & 1.45 & 3.13 & 2.64 \\
\hline Palmitic (C16:1) (\%) & 17.05 & 10.15 & 9.82 & 21.94 & 17.79 \\
\hline Oleic (C18:1) (\%) & 51.32 & 30.22 & 31.05 & 29.07 & 41.7 \\
\hline CLA (C18:2) $(\%)$ & 6.2 & nd & nd & 1.92 & 2.81 \\
\hline Lysine (mg kg $\left.{ }^{-1}\right)$ & 1026.82 & 268.25 & 789.24 & 560.91 & 566.13 \\
\hline Iso-Leucine ( $\left.\mathrm{mg} \mathrm{kg}^{-1}\right)$ & 381.84 & 218 & 36.84 & 341.19 & 489.35 \\
\hline Threonine (mg kg ${ }^{-1}$ ) & 406.26 & 200.34 & 403.02 & 410.73 & 414.19 \\
\hline Valine $\left(\mathrm{mg} \mathrm{kg}^{-1}\right)$ & 555.71 & 25.50 & 212.34 & 342.71 & 488.49 \\
\hline EAAI & 32.99 & 21.12 & 20.99 & 32.48 & 32.37 \\
\hline
\end{tabular}

Note: $\mathrm{A}=$ control, B= de Maan Rogosa Sharpe Broth (MRSB) + inulin 0.5\%, C= MRSB + mannan oligosaccharides (MOS), D= L. plantarum AKK30 (107 cfu $\left.\mathrm{g}^{-1}\right)+\mathrm{MRSB}+$ inulin $0.5 \%$, and $\mathrm{E}=\mathrm{L}$. plantarum AKK30 $\left(10^{7} \mathrm{cfu} \mathrm{g}^{-1}\right)+\mathrm{MRSB}+\mathrm{MOS} 0.5 \%$. nd= not detected, CLA= conjugated linoleic acid, EAAI= essential amino acid index. Means in the same row with different superscripts differ significantly $(\mathrm{p}<0.05)$. 
A

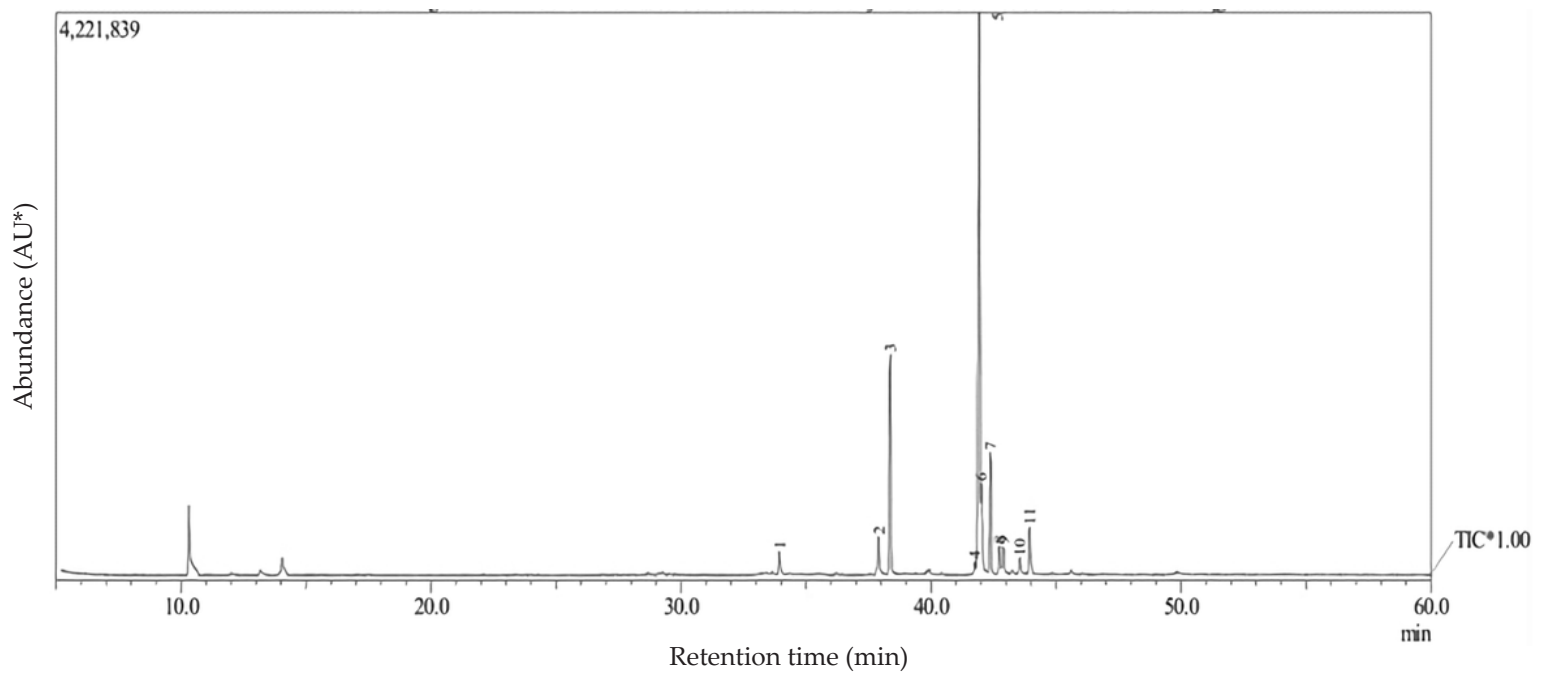

B

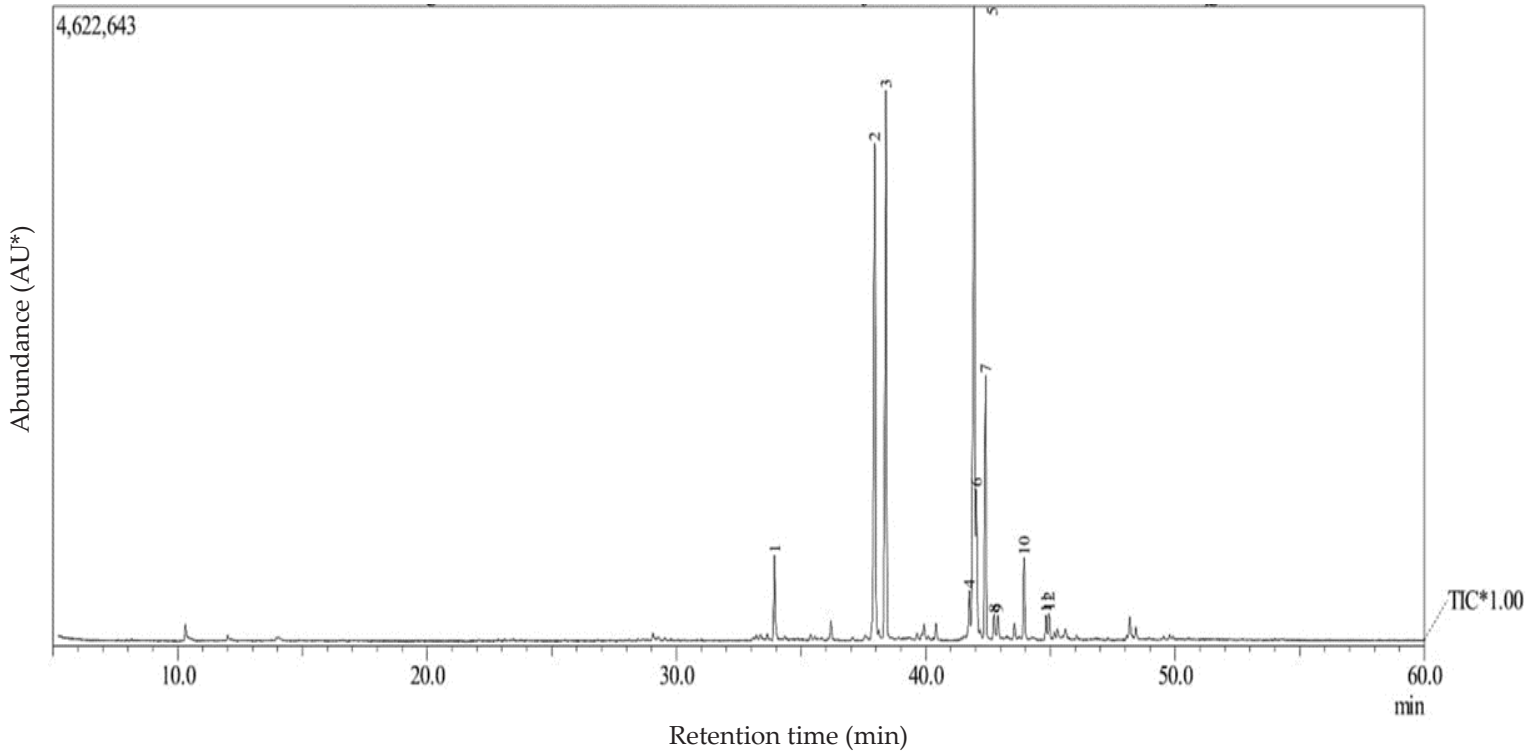

C

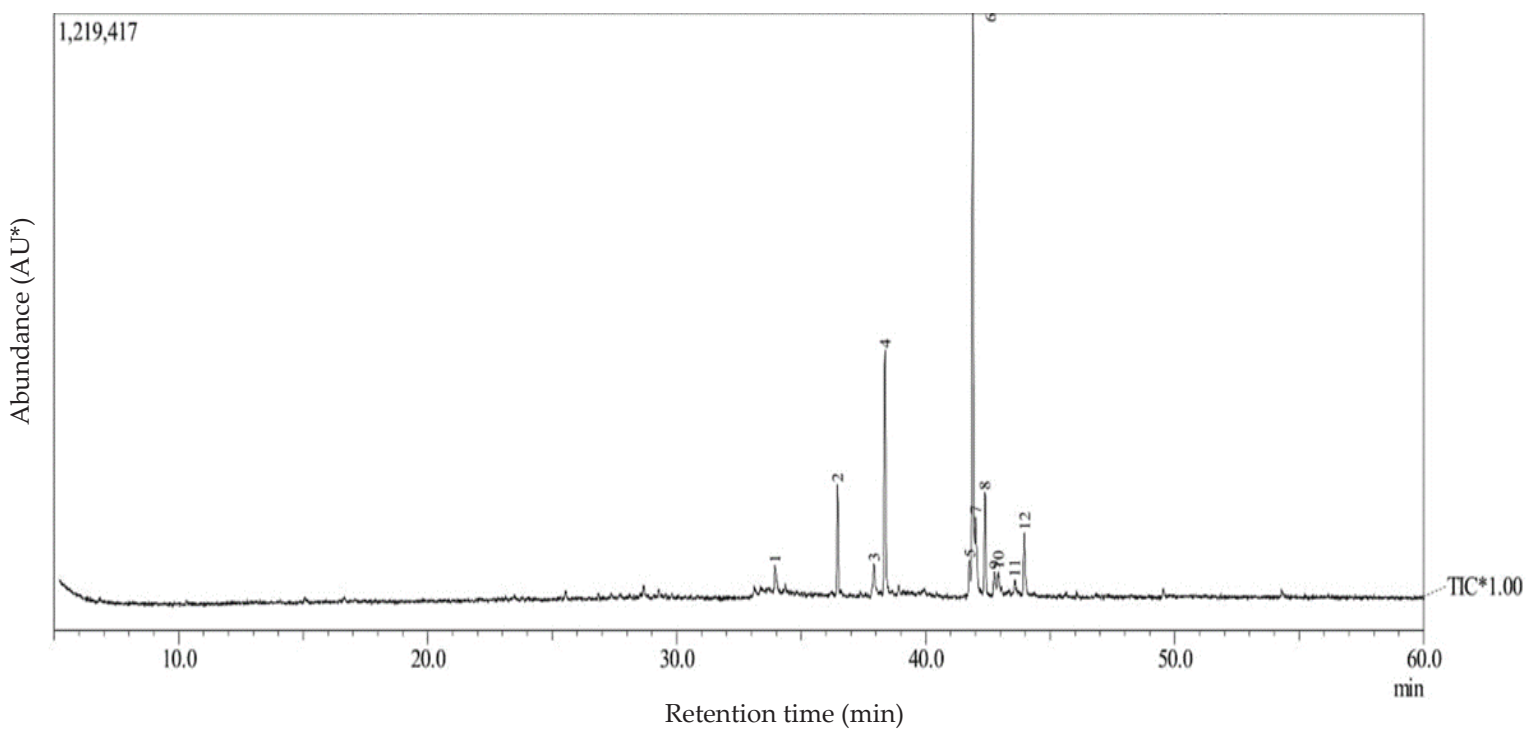

Figure 1. Chromatogram of control group (culture) (a), culture with inulin $0.5 \%\left(\mathrm{w} \mathrm{v}^{-1}\right)(\mathrm{b})$, and culture with MOS $0.5 \%$ $\left(\mathrm{w} \mathrm{v}^{-1}\right)(\mathrm{c}){ }^{*}=$ Arbitrary unit, $1=$ Myristic acid, $2=$ Palmitoleic acid, $3=$ Palmitic acid, $4=$ Palmitolinoleic acid, $5=$ Oleic acid, 6= Vaccenic acid, 7= Stearic acid, 8-9= Conjugated linoleic acids. 


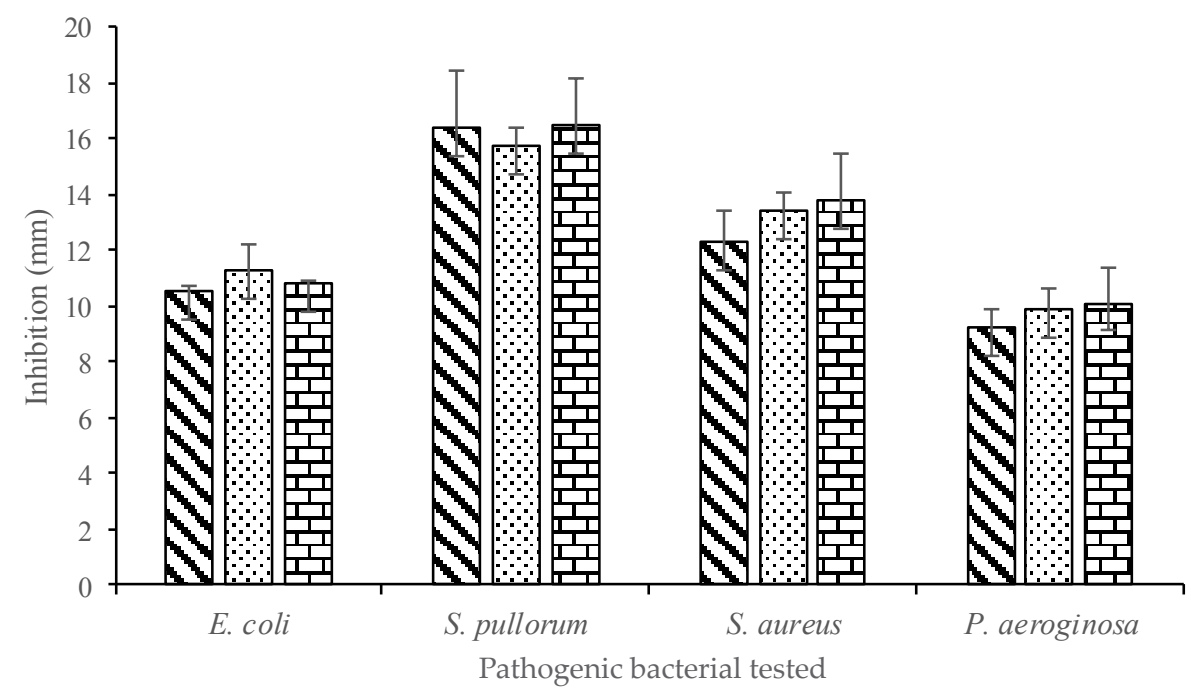

Figure 2. Inhibition of pathogenic bacterial growth by symbiotic consisted of L. plantarum and oligosaccharides, $\mathbf{\nabla}=$ LpAKK30, 0 = LpAKK30 + Inulin, 囲 = LpAKK30 + MOS.

Table 3. Nutrient utilizations and villous height of broilers treated by Lactobacillus plantarum AKK30 - Oligosaccharides

\begin{tabular}{lrrrrr}
\hline \multirow{2}{*}{ Variables } & \multicolumn{5}{c}{ Treatments } \\
\cline { 2 - 6 } & \multicolumn{1}{c}{$\mathrm{A}$} & \multicolumn{1}{c}{$\mathrm{B}$} & $\mathrm{C}$ & $\mathrm{D}$ \\
\hline Weight of excreta $(\mathrm{g} \mathrm{DM})$ & $64.10 \pm 23.32^{\mathrm{a}}$ & $64.39 \pm 13.00^{\mathrm{ab}}$ & $72.27 \pm 21.94^{\mathrm{a}}$ & $45.84 \pm 18.13^{\mathrm{b}}$ & $56.05 \pm 21.69^{\mathrm{b}}$ \\
N-excreta $(\mathrm{g} \mathrm{DM})$ & $9.68 \pm 12.61^{\mathrm{a}}$ & $11.44 \pm 17.73^{\mathrm{a}}$ & $9.11 \pm 11.51^{\mathrm{a}}$ & $8.78 \pm 13.58^{\mathrm{b}}$ & $9.70 \pm 16.59^{\mathrm{a}}$ \\
GE-excreta $\left(\mathrm{kcal} \mathrm{kg}^{-1}\right)$ & $2289.27 \pm 24.13^{\mathrm{a}}$ & $2293.39 \pm 18.41^{\mathrm{a}}$ & $2598.72 \pm 20.04^{\mathrm{a}}$ & $1708.23 \pm 15.62^{\mathrm{b}}$ & $1938.60 \pm 23.08^{\mathrm{b}}$ \\
AME $\left(\mathrm{kcal} \mathrm{kg}^{-1}\right)$ & $2876.34 \pm 2.55^{\mathrm{a}}$ & $3015.24 \pm 4.64^{\mathrm{ab}}$ & $2910.29 \pm 1.65^{\mathrm{a}}$ & $3119.44 \pm 4.42^{\mathrm{b}}$ & $3106.53 \pm 3.07^{\mathrm{b}}$ \\
TME $\left(\mathrm{kcal} \mathrm{kg}^{-1}\right)$ & $2988.50 \pm 2.45^{\mathrm{a}}$ & $3121.83 \pm 4.44^{\mathrm{ab}}$ & $3015.10 \pm 1.61^{\mathrm{a}}$ & $3217.19 \pm 4.37^{\mathrm{b}}$ & $3202.86 \pm 2.93^{\mathrm{b}}$ \\
TMEn $\left(\mathrm{kcal} \mathrm{kg}^{-1}\right)$ & $2989.37 \pm 2.45^{\mathrm{a}}$ & $3122.80 \pm 4.44^{\mathrm{ab}}$ & $3015.89 \pm 1.60^{\mathrm{a}}$ & $3218.19 \pm 4.37^{\mathrm{b}}$ & $3203.81 \pm 2.93^{\mathrm{b}}$ \\
NR $(\%)$ & $61.85 \pm 9.78^{\mathrm{ab}}$ & $66.41 \pm 8.17^{\mathrm{ab}}$ & $56.36 \pm 12.45^{\mathrm{a}}$ & $70.83 \pm 6.07^{\mathrm{b}}$ & $67.07 \pm 10.96^{\mathrm{b}}$ \\
Villous height $(\mu \mathrm{m})$ & $582.00 \pm 18.15^{\mathrm{a}}$ & $769.30 \pm 3.98^{\mathrm{b}}$ & $729.30 \pm 11.30^{\mathrm{b}}$ & $877.60 \pm 4.46^{\mathrm{b}}$ & $841.60 \pm 11.58^{\mathrm{b}}$ \\
\hline
\end{tabular}

Note: $\mathrm{A}=$ control, $\mathrm{B}=$ de Maan Rogosa Sharpe Broth (MRSB) + inulin 0.5\%, C= MRSB + mannan oligosaccharides (MOS), D= L. plantarum AKK30 (107 cfu $\left.\mathrm{g}^{-1}\right)+\mathrm{MRSB}+$ inulin $0.5 \%$, and $\mathrm{E}=\mathrm{L}$. plantarum AKK30 $\left(10^{7} \mathrm{cfu}^{-1}\right)+\mathrm{MRSB}+\mathrm{MOS} 0.5 \%$. GE = gross energy, AME =apparent metabolizable energy, $\mathrm{TME}=$ true metabolizable energy, TMEn = true metabolizable energy with nitrogen correction, NR= nitrogen retention. Means in the same row with different superscripts differ significantly $(\mathrm{p}<0.05)$.

$\mathrm{B}$, and $\mathrm{C}$ had the jejunum villus with the heights of 841.6 $\mu \mathrm{m}, 877.6 \mu \mathrm{m}, 769.3 \mu \mathrm{m}$, and $729.3 \mu \mathrm{m}$, respectively, that were significantly higher $(p<0.05)$ compared to control broilers treated with inoculum in MRSB without oligosaccharides (Group A) having the jejunum villus at the height of $582 \mu \mathrm{m}$. Those results indicated that the treatment significantly $(p<0.05)$ increased the intestinal morphology of broiler, compared to the control broiler without oligosaccharides treatment.

\section{Interrelationship Between Parameters}

The results of PCA (Figure 4) showed that the effects of treatment with L. plantarum AKK30 added with oligosaccharides (inulin or MOS) on some parameters were significantly different. There was interaction between L. plantarum AKK30 and enrichment with oligosaccharides on nutrients utilization and intestinal morphology. As shown in Figure 4, the contribution of oligosaccharides to L. plantarum AKK30 was relatively strong. The majority of parameters approached the main axis. These results imply that the smaller the cosine angle formed then the closer the relationship between inulin and MOS with L. plantarum AKK30. Factors affecting L. plantarum AKK30 were energy metabolism, nitrogen retention, optical density, $\mathrm{pH}$, fatty acids, and amino acids. Antibacterial activity did not require additional inulin and MOS although the viability of $L$. plantarum AKK30 was increased.

\section{DISCUSSION}

Some important fatty acids such as oleic, palmitic, myristic, and CLA were found in the culture media $L$. plantarum AKK30 with inulin and MOS, but CLA was not found (Figure 1). The difference in fatty acid contents possibly correlated with the composition of culture media from oligosaccharides such as inulin and MOS, especially the carbon source and glucose source, as were previously reported by Soto (2013). Inulin (Birmani et al., 2019) and MOS (Rageb et al., 2018) can supply enough glucose to L. plantarum. CLA is not found in MRSB media containing oligosaccharides and this condition is interesting to discuss in more detail. This result 

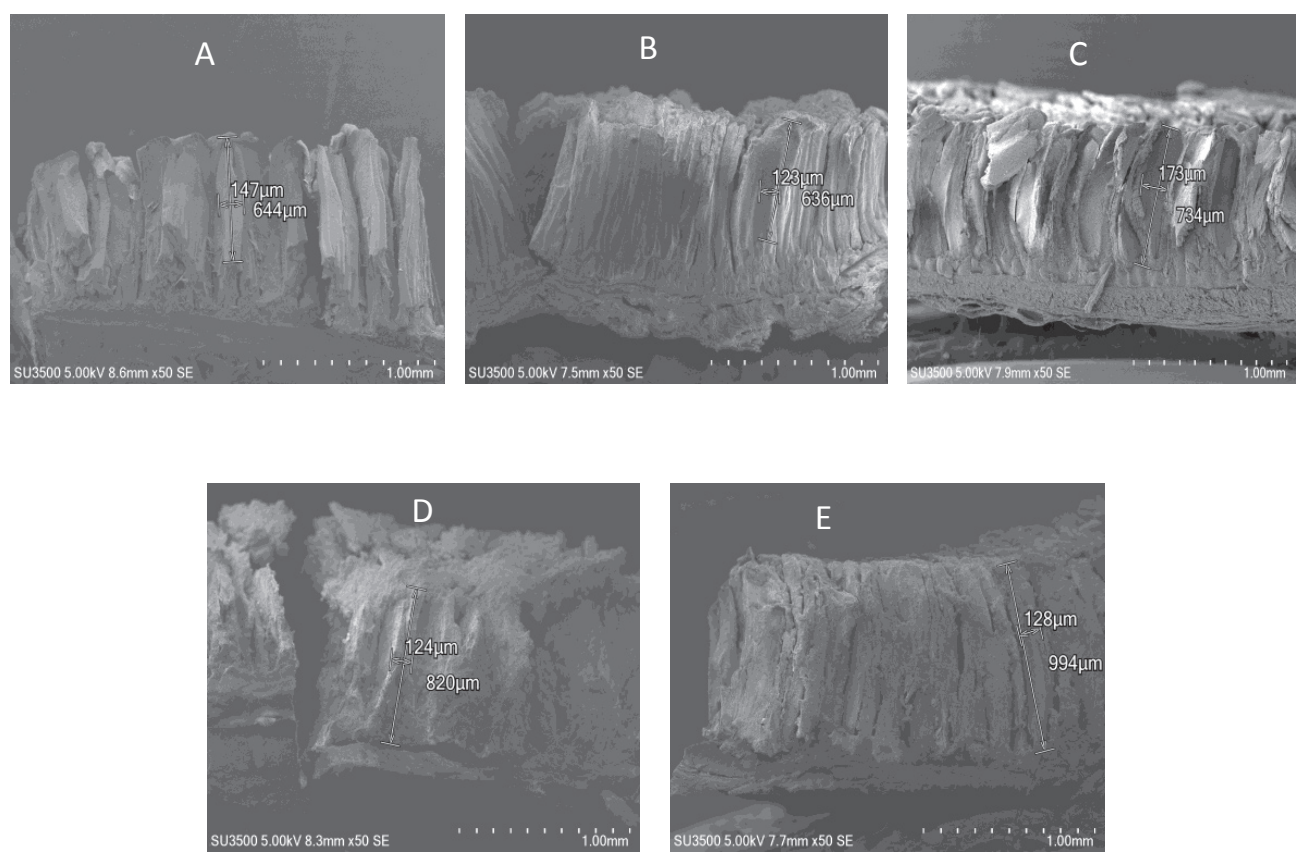

Figure 3. Scanning electron microscopy image of jejunum villi of broilers treated with symbiotic consisted of L. plantarum and oligosaccharides. A= control, B= mannan oligosaccharides (MOS), $\mathrm{C}=$ inulin, $\mathrm{D}=$ L. plantarum $\mathrm{AKK} 30\left(10^{7} \mathrm{cfu} \mathrm{g}^{-1}\right)$-inulin, and $\mathrm{E}=$ L. plantarum $\mathrm{AKK} 30$ $\left(10^{7} \mathrm{cfu} \mathrm{g}^{-1}\right)$-MOS.

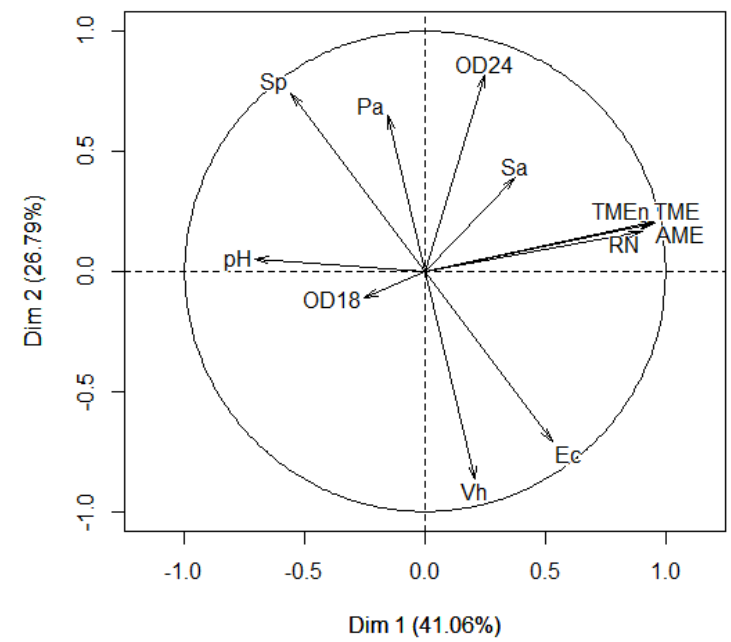

Figure 4. Principal component analysis visualizing the relationship between inhibition activity, optical density, and nutrient utilization. Dim 1= the first principal component explained by $41.06 \%$ of total variations, Dim $2=$ the second principal component explained by $26.79 \%$ of total variations $\mathrm{AME}=$ apparent metabolism energy, $\mathrm{TME}=$ true metabolism energy, $\mathrm{TMEn}=$ true metabolism energy nitrogen correction, $\mathrm{RN}=$ nitrogen retention, $\mathrm{OD}=$ optical density, $\mathrm{Sa}=\mathrm{S}$. aerus, $\mathrm{Sp}=\mathrm{S}$. pullorum, $\mathrm{Ec}=$ E. coli, $\mathrm{Pa}=$ P. aeruginosa .

showed that L. plantarum could metabolize CLA and the possible potency of enzymes in L. plantarum AKK30 to hydrolyze inulin and MOS to produce different levels of fatty acids. Inulin and MOS are water-soluble substances but cannot be enzymatically hydrolyzed in the intestine (Adebola et al., 2014) or hydrolyzed by probiotics (Pranckute et al., 2016).

Table 2 showed that the L. plantarum AKK30 culture media with MOS altered the composition of the amino acids, i.e., threonine and isoleucine. For synthesizing amino acids, L. plantarum AKK30 requires MOS to balance the GIT microflora (Rageb et al., 2018) because the amino acid synthesis depended on intestinal microflora conditions such as $\mathrm{pH}$ and proteolytic action of endogenous microbial enzymes (Wang et al., 2016). Index of essential amino acid (EAAI) in L. plantarum AKK30 is evidenced that the synbiotic contains amino acids and affect the nutrient utilization. Amino acids in synbiotic improved intra-cellular proteolytic activity (Zhang et al., 2016) to increase nutrient utilization in chicken (Alagawany et al., 2018).

Optical density of L plantarum AKK30 in combination with MOS and inulin indicated that the stationary phase occurred at 18 and 24 hours, respectively, which was different from control. There was an influence of oligosaccharides addition on the growth of L plantarum AKK30, while there was no significant difference between inulin and MOS additions. It might indicate the associative effect between the growth of L. plantarum AKK30 and oligosaccharides. This effect occurred because monosaccharides from fermented carbohydrates in the intestine are used as an energy source for the growth of L plantarum AKK30. Inulin can be hydrolyzed by $\beta$-fructan fructose hydrolases enzyme, its enzyme could remove the end fructose residue and acts on the internal link (De Oliveira et al., 2011). The solubility of inulin at room temperature was only $10 \%$ and inulin and MOS were not hydrolyzed by digestive enzymes 
in monogastric animals (Gibson et al., 2017). MOS is an indigestible short-chain polymer that can improve the utilization of energy and improve the modulatory of the GIT microflora in broilers (Yang et al., 2008). Thus, inulin and MOS as glucose sources for the lactic acid bacteria and can assimilate the process of fermentation by lactic acid bacteria.

L. plantarum AKK30 has antibacterial activity against gram-negative and positive pathogenic bacteria (Table 2). There was no effect of oligosaccharides addition on the antibacterial activity of L. plantarum AKK30 even though the viability of $L$ plantarum AKK30 increased with the addition of inulin and MOS. Palaniyandi et al. (2017) reported that lactic acid bacteria have inhibition activity against gram-positive pathogenic bacteria (i.e. E. coli and P. aeruginosa). Lactic acid bacteria such as L. plantarum produced bacteriocins antimicrobial peptides 'plantaricin' and it can kill pathogenic bacteria at the cellular and molecular levels (Wang et al., 2019). Bacteriocins of L. plantarum AKK30 inhibited the growth of Staphylococcus aureus, Salmonella pullorum, Escherichia coli, and Pseudomonas aeruginosa. In contrast, the antibacterial activity of L plantarum AKK30 was not affected by inulin and MOS (Figure 2). This effect was possibly caused by oligosaccharides such as MOS and inulin have no antibacterial activity, but it increased the growth of probiotic bacteria (Pranckute et al., 2016) because oligosaccharides are used as a nutrient for lactic acid bacteria (Gibson et al., 2017).

This study proved that nitrogen and energy content in excreta of broiler offered synbiotic L. plantarum AKK $30+$ inulin was significantly different $(p<0.05)$ from the other treatments (Table 2). The amount of feed consumed might be linear with the amount of feed digested but not necessarily linear with the nutrients absorbed, because residual feed intake is always present in the digesta (Metzler-Zebeli et al., 2018). Residual feed intake in the digesta is food that was not absorbed by the body that was subsequently secreted into the excreta. The un-optimal nutritional absorption might be associated with the high population of pathogenic bacteria, which affects the health of the intestinal microflora of the broiler (Alonge et al., 2017). This proves that the synergy of L. plantarum AKK 30 and inulin has functioned as a probiotic because it could nourish the intestinal microflora, since the absorption of nutrients is affected by the intestinal microflora (Yan et al., 2017) and villous performance (Coskun et al., 2017). These pathogenic bacteria could be suppressed by synbiotic Lactobacillus and oligosaccharides so that the environment of the intestinal microflora and development of villi would be optimized by allowing the increase levels of absorbed nutrients (Yan et al., 2017).

Probiotics that provide a beneficial effect on nutritional absorption is still unclear (Roberts et al., 2015). This study showed that the administration of synbiotic could increase TME and TMEn compared to control and MOS. There was a tendency for synbiotic L. plantarum AKK-30+inulin to increase ME value compared with the other treatments that was similar to the observations previously reported by Ahmed et al. (2018).
Monosaccharides from fermented carbohydrates in the intestine directly stimulate the proliferation of epithelial cells (Roberfroid et al., 2010; Ajuwon, 2016). Intestinal epithelial cells and enzyme activity in the digestive tract are maintained by probiotics, so that stimulates the absorption of the increased nutrients (Wang et al., 2016), including feed energy sources (Santos et al., 2015).

Oligosaccharides are needed by probiotics to increase the viability and population of L. plantarum (Ravangard et al., 2017) and to provide a healthy effect on the host (Cao et al., 2019). Fermentations of oligosaccharides are sources of nutrients for probiotic bacteria, thus increasing its viability (Prancute et al., 2016). Oligosaccharides, including MOS and inulin are used selectively by certain microorganisms (Gibson et al., 2017). While intestinal $\mathrm{pH}$ is reduced by the increasing bacterial population, the viability of pathogenic bacteria can be potentially reduced (Zhu et al., 2006). Therefore, synbiotic probiotics and oligosaccharides are needed so that the Lactobacillus population will be higher and potentially live longer in the chicken intestine. The antibacterial activity could be enhanced by the supplementation of synbiotic (oligosaccharides and probiotic) (Prancute et al., 2016).

Metabolic energy parameters (AME, TME, and TMEn) and nitrogen retention (NR) in broilers treated with synbiotic L. plantarum AKK30-inulin were higher than those in L. plantarum AKK30-MOS, even though both treatments were significantly different from the control $(p<0.05)$. This result showed that there was a relationship between lactic acid bacteria and oligosaccharides, because oligosaccharides as a source of nutrition for the growth of lactic acid bacteria. Moreover, Baurhoo et al. (2007) reported that MOS could inhibit the growth of pathogenic bacteria in the intestine. Some oligosaccharides, such as inulin and MOS, can be synergized with Lactobacillus (Schrezenmeir \& deVrese, 2001). Synbiotic (Lactobacillus-oligosaccharides) can increase the production of bacterial metabolites that influence the environment of intestinal microbiota and immunity (Wilson \& Whelan, 2016). Roberfroid et al. (2010) revealed that the presence of oligosaccharides promotes the growth of lactic acid bacteria i.e., Bifidobacteria and Lactobacilli. Inulin was more likely to be synbiotic with Lactobacilli because inulin could be hydrolyzed by the $\beta$-fructofuranosidase enzyme so that it increases the growth of Lactobacilli (Wilson \& Whelan, 2016).

In this study, nitrogen retention in all treatments was positive, meaning that the quality and protein content of the feed was treated well, as was recommended by Jimenez et al. (2013). The high NR was possibly correlated with the oligosaccharides content of the feed (Thorat et al., 2015) so that the existence of synbiotic in the intestine improved proteolysis activity and created a healthier intestinal environment (Wealleans et al., 2017).The improved nitrogen retention by the supplementation of synbiotic in the present study may be contributed by the improved gut health by the synbiotic by reducing the load of pathogenic bacteria thereby improving nutrition utilization. It was proven that syn- 
biotic L. plantarum with oligosaccharides activity, such as MOS and inulin, could improve food digestion and nutrient absorption.

The improvement of NR in the synbiotic group could be due to the partial hydrolysis of non-starch polysaccharides, thereby reducing the viscosity of gut contents (Thorat et al., 2015) and resulting in the improved nutrients utilization (Alagawany et al., 2018). Nitrogen retention possibly associated with a healthier intestinal environment (Thorat et al., 2015). Effect of synbiotic treatments on villus height was shown in Table 3 and explained in Figure 2.

Using the SEM (Figure 2), we observed that synbiotic L. plantarum with oligosaccharides (inulin and MOS) showed the increased villus height in jejunum epithelia. The positive effect of synbiotic is possibly due to the modulating and maintaining effects on cell functions and integrities, in accordance with the observations in the previous study (Franz et al., 2017). In this study, L. plantarum improved the morphology of intestine in broiler chickens administered with different oligosaccharides, compared with the control. The symbiosis of $L$. plantarum AKK30-inulin and L. plantarum AKK30-MOS has antibacterial abilities in the chicken intestine, which potentially replace the use of antibiotic growth promoters. Lactobacillus plantarum could effectively regulate the immune response of intestinal mucosal and improve the structures of villi in broiler chickens (Cao et al., 2019). The population of pathogenic bacteria in the intestinal mucosa can be reduced by treatment with synbiotic $L$. plantarum AKK30-inulin and L. plantarum AKK30-MOS, thereby increasing the performance of villi in the intestine. The density, length, and surface area of villi in the small intestine can be influenced by probiotics (Olnood et al., 2015) and protein of cytoskeleton might affect the height of intestinal villi and associated with intestinal lumen (Franz et al., 2017; Cao et al., 2019). Shortening villi imply the reduction of surface area in the digestion tract and possibly impaired the digestive system and nutrients absorption (Kavoi et al., 2016). L. plantarum effectively regulated the immune responses of the intestinal mucosal system and improved the structures of villi in broiler chickens (Cao et al., 2019).

Overall, synbiotic affected energy metabolism and protein digestibility in the intestine, because synbiotic inhibited pathogenic bacteria in the intestine. There is a correlation in the digestibility and the growth of pathogenic bacteria in the intestine, i.e., the higher the population of pathogenic bacteria the higher the number of undigested nutrients. These results suggested that supplementation of L. plantarum AKK30 in quails diet increased nutrient digestibility mainly nitrogen retention as previously reported by Sofyan et al. (2019).

\section{CONCLUSION}

Inclusion of oligosaccharides inulin or mannan oligosaccharide (MOS) affects the metabolite profiles of Lactobacillus plantarum AKK-30 by in vitro assays. Supplementation of Lactobacillus plantarum AKK-30 + inulin improved the intestinal morphology, metabolizable energy, and nitrogen retention in broilers chicken.

\section{CONFLICT OF INTEREST}

The authors declare that there is no conflict of interest with any financial, personal, or other relationships with other people or organization related to the material discussed in the manuscript.

\section{ACKNOWLEDGEMENT}

This study was supported by the HIBAH PITTA research program of Universitas Indonesia (UI) and Thematic Research Program - DIPA 2018 in Research Division of Natural Product Technology (BPTBA), Indonesian Institute of Sciences (LIPI). The authors thank to M. Anwar, M.Sc. and A. Windarsih, M.Pharm. Sci. for helping the GCMS data interpretation.

\section{REFERENCES}

Adebola, O. O., O. Corcoran, \& W. A. Morgan. 2014. Synbiotics: the impact of potential prebiotics inulin, lactulose and lactobionic acid on the survival and growth of lactobacilli probiotics. J. Funct. Food. 10: 75-48. https://doi.org/10.1016/j. jff.2014.05.010

Ahmed, M.M.N., Z.S.H. Ismail, \& A.A.A. Abdel-Wareth. 2018 Effect of dietary supplementation of prebiotic, betaine and their combination on growth performance, nutrient digestibility, carcass criteria and cecum microbial population of ducks under hot environmental conditions. Egypt. Poult. Sci. 38:289-304. https://doi.org/10.21608/epsj.2018.5666

Ajuwon, J.M. 2016. Toward a better understanding of mechanisms of probiotics and prebiotics action in poultry species. J. Appl. Poult. Res., 25:277-283. https://doi.org/10.3382/ japr/pfv074

Alagawany, M., M.E. Abd El-Hack, M.R. Farag, S. Sachan, K. Karthik, \& K. Dhama. 2018. The use of probiotics as eco-friendly alternatives for antibiotics in poultry nutrition. Environ. Sci. Pollut. Res. 25:10611-10618. https://doi. org/10.1007/s11356-018-1687-x

Alonge, E.O., D. Eruvbetine, O.M.O. Idowu, A.O. Obadina, \& O.O. Olukomaiya. 2017. Effect of dietary feed additives on hematological and serum biochemical parameters of broiler chickens. J. Anim. Feed Res. 7: 18-23.

AOAC. 2005. Official Methods of Analysis of AOAC International 18th ed. Assoc. Off. Anal. Chem., Arlington.

Apajalahti, J. \& K. Vienola. 2016. Interaction between chicken intestinal microbiota and protein digestion. Anim. Feed. Sci. Technol. 221: 323-330. https://doi.org/10.1016/j. anifeedsci.2016.05.004

Baurhoo, B., A. Letellier, Z. Xi, \& C. A. Ruiz- Feria. 2007. Cecal population of lactobacilli and bifidobacterial and Escherichia coli after in-vivo Escherichia coli challenge in birds fed diets with purified lignin or mannanoligosaccharides. Poult. Sci. 86: 2509-2516. https://doi.org/10.1093/ ps/86.6.1070

Birmani, M. W., A. Nawab, M. Ghani, G. Li, M. Xiao, \& L. An. 2019. A Review: role of inulin in animal nutrition. J. Food. Technol. Res. 6:18-27. https://doi.org/10.18488/ journal.58.2019.61.18.27

Bonev, B., H. James, \& P. Judacael. 2008. Principles of assessing bacterial susceptibility to antibiotics using the agar diffusion method. J. Antimicrob. Chem. 61:1295-1301. https:// doi.org/10.1093/jac/dkn090

Cao, L., X.H. Wu, Y.L. Bai, X.Y. Wu, \& S.B. Gu. 2019. Antiinflammatory and antioxidant activities of probiotic powder containing Lactobacillus plantarum 1.2567 in necrotic enteritis model of broiler chickens. Livest. Sci. 223: 157-163. 
https://doi.org/10.1016/j.livsci.2019.03.009

Chang, C.H., P. Y. Teng, T.T. Lee, \& Y. Bi. 2019. Effects of multistrain probiotics combined with Gardeniae fructus on intestinal microbiota, metabolites, and morphology in broilers. J. Poult. Sci. 56: 32-43. https://doi.org/10.2141/jpsa.0170179

Cohort. 2005. Costat-Coplot Version 6.311. Cohort Software798 Light House Ave. PMB320. Monterey. CA93940 and USA.

Coskun, I.G., G. Erener, H. Cayiroglu, A. Altop, H. Cayan, \& A. Sahin. 2017. Effects of dietary synbiotic supplementation on growth performance and duodenum histology of Japanese quail (Coturnix coturnix Japonica) reared in different flooring systems. Rev. Bras. Zootecn. 46: 800-804. https://doi.org/10.1590/s1806-92902017001000002

De Oliveira, A.J.B., R.A.C. Gonçalves, T. P. C. Chierrito, M.M. dos Santos, L. M. de Souza, P.A.J. Gorin, G.L. Sassaki, \& M. Iacomini. 2011. Structure and degree of polymerisation of fructooligosaccharides present in roots and leaves of Stevia rebaudiana (Bert.) Bertoni. Food Chem. 129: 305-311. https://doi.org/10.1016/j.foodchem.2011.04.057

Filho, F.D.E., K.A.A. Torres, D.E. Faria, D.M.B. Campos, \& P.S. Rosa. 2006. Probiotics for broiler chickens in Brazil: systematic review and meta-analysis. Braz. J. Poult. Sci. 8: 89-98. https://doi.org/10.1590/S1516-635X2006000200004

Forkus, B., S. Ritter, M. Vlysidis, K. Geldart, \& Y. N. Kaznessis. 2017. Antimicrobial probiotics reduce Salmonella enterica in turkey gastrointestinal tracts. Sci. Rep. 7: 40695. https://doi. org/10.1038/srep40695

Franz, J., M. Tarantola, \& C. Riethmuller. 2017. How tetraspanins shape endothelial and leukocyte nano-architecture during inflammation. Biochem. Soc. Trans. 45: 999-1006. https://doi.org/10.1042/BST20170163

Gibson, G.R., R. Hutkins, M. F. Sanders, S. L. Prescott, R. A. Reimer, S. J. Salminen, K. Scott, C. Stanton, K. S. Swanson, P. D. Cani, \& K. Verbeke. 2017. Expert consensus document: The international scientific association for probiotics and prebiotics (ISAPP) consensus statement on the definition and scope of prebiotics.Nat. Rev. Gastro. Hepat. 14:491. https://doi.org/10.1038/nrgastro.2017.75.

Istiqomah, L., A. Sofyan, E. Damayanti, \& H. Julendra. 2009. Amino acid profile of earthworm and earthworm meal (Lumbricus rubellus) for animal feedstuff. J. Indones. Trop. Anim. Agric. 34:253-257. https://doi.org/34.10.14710/ jitaa.34.4.253-257

Jimenez, E.M., M. Frikha, A. de Coca Sinova, J. Garcia, \& G.G. Mateos. 2013. Oat hulls and sugar beet pulp in diet of broilers; effect on growth performance and nutrient digestibility. Anim. Feed. Sci. Technol. 182: 33-43. https://doi. org/10.1016/j.anifeedsci.2013.03.011

Kavoi, B. M., D. W. Gakuya, P. N. Mbugua, \& S. G. Kiama. 2016. Effects of dietary Moringa oleifera leaf meal supplementation on chicken intestinal structure and growth performance. J. Morphol. Sci. 33: 186-192. http://dx.doi. org/10.4322/jms.095915

Metzler-Zebeli, B.U., E. Magowan, M. Hollmann, M.E.E. Ball, A. Moln'ar, K. Witter, R. Ertl, R.J. Hawken, P.G. Lawlor, N.E. O'Connell, J. Aschenbach, \& Q. Zebeli. 2018. Differences in intestinal size, structure, and function contributing to feed efficiency in broiler chickens reared at geographically distant locations. Poult. Sci. 97: 578-591. https://doi.org/10.3382/ps/pex332

McGlone, J. 2010. Guide for The Care and Use of Agricultural Animals in Research and Teaching. Fed. Anim. Sci. Soc. 3th ed. https://www.aaalac.org/ [5 May 2019].

National Research Council (NRC). 1994. Nutrient Requirements of Poultry. 9th Revised Edition. National Academy Press, Washington DC. USA.

Olnood, C.G., S.M.B. Sleman, C. Mingan, \& A.I. Paul. 2015. Novel probiotics: their effects on growth performance, gut development, microbial community and activity of broiler chickens. Anim. Nutr. 1: 184-191. https://doi.org/10.1016/j. aninu.2015.07.003

Palaniyandi, S.A., D. Karthiyaini, W.S. Joo, \& H.Y. Seung. 2017. In vitro characterization of Lactobacillus plantarum strains with inhibitory activity on enteropathogens for use as potential animal probiotics. Indian J. Microbiol. 57: 201. https://doi.org/10.1007/s12088-017-0646-4

Peng, Q., X.F. Zeng, J. L. Zhu, S. Wang, X. T. Liu, C. L. Hou, P. A. Thacker, \& S.Y. Qiao. 2016. Effects of dietary Lactobacillus plantarum B1 on growth performance, intestinal microbiota, and short chain fatty acid profiles in broiler chickens. Poult. Sci. 95: 893-900. https://dx.doi.org/10.3382/ ps/pev435

Pourabedin, M. \& X. Zhao. 2015. Prebiotics and gut microbiota in chickens. FEMS Microbiol. Lett. 362: 1-8. https://doi. org/10.1093/femsle/fnv122

Pranckute, R., K. Arnoldas, K. Nomeda, \& J.C. Donaldas. 2016. Combining prebiotics with probiotic bacteria can enhance bacterial growth and secretion of bacteriocins. Int. J. Biol. Macromol. 89: 669-676. https://doi.org/10.1016/j. ijbiomac.2016.05.041

Rageb, M. M. S., E.A. Abd-Allah, N.S. Abu-Khalil, F.M. Abdel-Maksoud, \& U.T. Mahmoud. 2018. Effect of mannan-oligosaccharides and B-glucan prebiotics on the brain oxidant/ antioxidant balance in broiler under natural egyptian summer conditions. Egypt Acad. J. Biol. Sci., B. Zool. 10: 35-46. https://doi.org/10.21608/eajbsz.2018.13428

Ravangard, A.H., M. Houshmand, M. Khajavi \& R. Naghiha. 2017. Performance and cecal bacteria counts of broilers fed low protein diets with and without a combination of probiotic and prebiotic. Braz. J. Poult. Sci. 19: 75-82. https:// doi.org/10.1590/1806-9061-2016-0319

Roberfroid, M., G.R. Gibson, \& L. Hoyles. 2010. Prebiotic effects: metabolic and health benefits. Br. J. Nutr. 104:51-63. https://doi.org/10.1017/S0007114510003363

Roberts, T., J. Wilson, A. Guthrie, K. Cookson, D. Vancraeynest, J. Schaeffer, R. Moody, \& S. Clark. 2015. New issues and science in broiler chicken intestinal health: Emerging technology and alternative interventions. J. Appl. Poult. Res. 24: 257-266. http://dx.doi.org/10.3382/japr/pfv023

Rodjan, P., K. Soisuwan, K. Thongprajukaew, Y. Theapparat, S. Khongthong, J. Jeenkeawpieam, \& T. Salaeharae. 2018. Effect of organic acids or probiotics alone or in combination on growth performance, nutrient digestibility, enzyme activities, intestinal morphology and gut microflora in broiler chickens. J. Anim. Physiol. Anim. Nutr. 102: e931-e940. https://doi.org/10.1111/jpn.12858

Rotaru, A.S., I.D. Pop, A. Vatca, \& A. Cioban. 2012. Usefulness of principal component analysis in agriculture. Bull. Univ. Agric. Sci. Vet. Hort. 69: 504-509. http://dx.doi. org/10.15835/buasvmcn-hort:8837

Santos, F.R., J.H. Stringhini, P.R. Oliveira, E.F. Duarte, C.S. Minafra \& M.B. Café. 2015. Values of metabolizable energy and metabolization of nutrients for slow- and fastgrowing birds at different ages. Braz. J. Poult. Sci. 17: 517522. https://doi.org/10.1590/1516-635X1704517-522

Schrezenmeir, J. \& M. deVrese. 2001. Probiotics, prebiotics, and synbiotics approaching a definition. Am. J. Clin. Nutr. 73:361-364. https://doi.org/10.1093/ajcn/73.2.361s

Sethiya, N.K. 2016. Review on natural growth promoters available for improving gut health of poultry: an alternative to antibiotic growth promoters. Asian. J. Poult. Sci. 10: 21-29. https://doi.org/10.3923/ajpsaj.2016

Sibbald, I. R. \& M.S. Wolynets. 1985. Relationships between estimates of bioavailable energy made with adult cockerels and chicks: effects of feed intake and nitrogen retention. Poult. Sci. 64: 127-138. https://doi.org/10.3382/ps.0640127

Sofyan, A., R. S. H. Martin, E. B. Laconi, A. Jayanegara, H. Julendra, E. Damayanti, \& A. E. Suryani. 2019. The assays 
of bacteria-yeast consortia as probiotics candidates and their influences on nutrients utilization of quails diet. Trop. Anim. Sci. J. 42: 196-202. https://doi.org/10.5398/ tasj.2019.42.3.196

Soto, C. 2013. Lactobacillus plantarum as source of conjugated linoleic acid: Effect of $\mathrm{pH}$, incubation temperature and inulin incorporation. J. Biochem. Technol. 5:649-653.

Thorat, S.G., V.S. Panwar, D.S. Dahiya, \& B.S. Tewatia. 2015. Efficacy of probiotics, prebiotics and enzymes as growth promoters on the performance of broiler chicken. Haryana Vet. 54:75-78.

Titze, B. \& G. Christel. 2016. Volume scanning electron microscopy for imaging biological ultrastructure. Biol. Cell. 108:307-337. https://doi.org/10.1111/boc.201600024

Tsirtsikos, P.K., K. Fegeros, C. Balaskas, A. Kominakis, \& K.C. Mountzouri. 2012. Dietary probiotic inclusion level modulates intestinal mucin composition and mucosal morphology in broilers. Poult. Sci. 91:1860-1868. https:// doi.org/10.3382/ps.2011-02005

USDA. 2017. National Nutrient Database for Standard Reference. Version Current. https://ndb.nal.usda.gov/ndb. [April 2019].

Wang, H. L., S. Meng, X. Xiao, P. Long, F.Z. Pan, K.M. Xiao, Y.T. Qi, \& S.P. Xiang. 2016. Effects of flavomycin, Bacillus licheniformis and enramycin on performance, nutrient digestibility, gut morphology and the intestinal microflora of broilers. J. Poult. Sci. 53: 128-135. https://doi.org/10.2141/ jpsa.0150077

Wang, Y., Q. Yuxuan, Z. Ying, W. Ruiyun, \& L. Pinglan. 2019. Antibacterial mechanism of plantaricin LPL-1, a novel class IIa bacteriocin against Listeria monocytogenes. Food Cont. 97: 87-93. http://doi.org/10.1016/j.foodcont.2018.10.025
Wealleans, A. L., M.C. Walsh, L.F. Romero, \& V. Ravindran. 2017. Comparative effects of two multi-enzyme combinations and a bacillus probiotic on growth performance, digestibility of energy and nutrients, disappearance of non-starch polysaccharides, and gut microflora in broiler chickens. Poult. Sci. 96:4287-4297. https://doi.org/10.3382/ ps/pex226

Wilson, B. \& K. Whelan. 2016. Prebiotic inulin-type fructans and galacto -oligosaccharides: definition, specificity, function, and application in gastrointestinal disorders. J. Gastroen. Hepatol. 32 (Suppl. 1): 64-68. https://doi. org/10.1111/jgh.13700

Yan, W., C. Sun, J. Yuan, \& N. Yang. 2017. Gut metagenomic analysis reveals prominent roles of lactobacillus and cecal microbiota in chicken feed efficiency. Sci. Rep. 7: 45308. https://doi.org/10.1038/srep45308

Yang, Y., P. Iji, A. Kocher, E. Thomson, L. Mikkelsen, \& M. Choct. 2008. Effects of mannanoligosaccharide in broiler chicken diets on growth performance, energy utilization, nutrient digestibility and intestinal microflora. Br. Poult. Sci. 49: 186-194. https://doi.org/10.1080/00071660801998613

Zhang, L., L. Zhang, X. Zeng, L. Zhou, G. Cao, \& C. Yang. 2016. Effects of dietary supplementation of probiotic, Clostridium butyricum, on growth performance, immune response, intestinal barrier function, and digestive enzyme activity in broiler chickens challenged with Escherichia coli K88. J. Anim. Sci. Biotechnol. 7: 3. https://doi.org/10.1186/ s40104-016-0061-4

Zhu, H., C.A. Hart, D. Sales, \& N.B. Roberts. 2006. Bacterial killing in gastric juice- effect of $\mathrm{pH}$ and pepsin on Escherichia coli and Helicobacter pylori. J. Med. Microbiol. 55: 1265-1270. https://doi.org/10.1099/jmm.0.46611-0 